University of Nebraska - Lincoln

DigitalCommons@University of Nebraska - Lincoln

$1-1-2004$

\title{
Effect of Distillers Grains or Corn Supplementation Frequency on Forage Intake and Digestibility
}

Tim W. Loy

University of Nebraska-Lincoln

James C. MacDonald

University of Nebraska-Lincoln, jmacdonald2@unl.edu

Terry J. Klopfenstein

University of Nebraska-Lincoln, tklopfenstein1@unl.edu

Galen E. Erickson

University of Nebraska-Lincoln, gerickson4@unl.edu

Follow this and additional works at: https://digitalcommons.unl.edu/animalscinbcr

Part of the Animal Sciences Commons

Loy, Tim W.; MacDonald, James C.; Klopfenstein, Terry J.; and Erickson, Galen E., "Effect of Distillers Grains or Corn Supplementation Frequency on Forage Intake and Digestibility" (2004). Nebraska Beef Cattle Reports. 200.

https://digitalcommons.unl.edu/animalscinbcr/200

This Article is brought to you for free and open access by the Animal Science Department at DigitalCommons@University of Nebraska - Lincoln. It has been accepted for inclusion in Nebraska Beef Cattle Reports by an authorized administrator of DigitalCommons@University of Nebraska - Lincoln. 


\section{Effect of Distillers Grains or Corn Supplementation Frequency on Forage Intake and Digestibility}

\author{
Tim W. Loy \\ Jim C. MacDonald \\ Terry J.Klopfenstein \\ Galen E. Erickson ${ }^{1}$
}

\section{Summary}

Ten ruminally cannulated heifers received no supplement, dry distillers grains (DDG) daily, DDG on alternating days, dry rolled corn daily, or corn on alternating days. Hay intake was higher for non-supplemented than for supplemented heifers. No intake differences were observed between DDG and corn-supplemented heifers. Heifers supplemented daily had higher and more consistent intakes than those in alternate-day treatments, particularly within corn-supplemented heifers. Ruminal $\mathrm{pH}$ and hay fiber disappearance were greater in non-supplemented heifers. Corn-supplemented heifers had slower rates of fiber disappearance than DDG-supplemented. Alternateday energy supplementation increased intake variability compared to daily supplementation.

\section{Introduction}

Supplementation programs are integral components of many ranching systems that are dependent on low-quality forages to meet some portion of their annual feeding needs. Feed costs often represent the largest variable cost incurred by a ranching operation.
Reducing the frequency of feeding supplement has been explored as one means of lowering the costs associated with supplementation programs.

In general, reducing feeding frequency has proven adequate when supplemental protein is being fed, presumably due to ruminants' ability to recycle N. Irregular feeding of energy supplements has proven less effective, often leading to reduced performance. However, energy supplements are typically grain based, and therefore contain significant amounts of starch. By reducing feeding frequency, more supplement is required per feeding, which can result in large amounts of starch being consumed at one time. This may lead to a depression in forage utilization due to a negative associative effect between starch and forage digestibility.

Many byproducts available to livestock producers contain large amounts of digestible fiber. These feeds provide energy in a form that may not inhibit utilization of forage. Distillers grains, a byproduct of the ethanol manufacturing industry, is high in digestible fiber, and may be a suitable supplement to high-forage diets. Research conducted at the University of Nebraska indicated that the energy value of dry distillers grains was about $125 \%$ the value of corn in a forage-based diet (2003 Nebraska Beef Report, pp. 8-10). The amount and form of energy found in distillers grains may provide an opportunity to reduce the frequency of energy supplementation without compromising forage utilization.

The objectives of this trial were to compare the effects of supplementation of distillers grains or corn, either daily or on alternate days, on intake and ruminal parameters.

\section{Procedure}

Ten ruminally cannulated heifers $(B W=917 \mathrm{lb})$ were used in a replicated Latin rectangle design, with four periods and five treatments, to test effects of supplemental energy form and frequency on intake and digestibility parameters.

Table 1. Composition (\%DM) of supplements fed to heifers provided ad libitum levels of grass hay.

\begin{tabular}{lcc}
\hline Ingredient & $\mathrm{DRC}^{\mathrm{a}}$ & $\mathrm{DDG}^{\mathrm{a}}$ \\
\hline $\begin{array}{l}\text { Dry rolled corn } \\
\text { Dry distillers grain }\end{array}$ & 86.8 & - \\
$\quad+$ solubles & - & 89.1 \\
Molasses & 5.4 & 5.6 \\
Urea & 2.6 & 1.6 \\
Limestone & 2.4 & 3.3 \\
Dicalcium phosphate & 2.4 & - \\
Vitamin pre-mix & 0.2 & 0.2 \\
Mineral pre-mix & 0.2 & 0.2
\end{tabular}

${ }^{\mathrm{a}} \mathrm{DRC}=$ dry rolled corn supplement fed at $0.46 \%$ of BW daily, or $0.92 \%$ of BW on alternate days; DDG $=$ dry distillers grains + solubles supplement fed at $0.45 \%$ of BW daily, or $0.90 \%$ of $\mathrm{BW}$ on alternate days. 
Table 2. Treatment effects on intake, neutral detergent fiber disappearance, ruminal $\mathrm{pH}$, and intake pattern.

\begin{tabular}{|c|c|c|c|c|c|}
\hline Item & $\mathrm{CON}^{\mathrm{a}}$ & DRC-D ${ }^{a}$ & $\mathrm{DRC}-\mathrm{A}^{\mathrm{a}}$ & DDG-Da & DDG-A ${ }^{a}$ \\
\hline Hay DMI, \%BW ${ }^{b}, c$ & 1.88 & 1.69 & 1.58 & 1.69 & 1.66 \\
\hline Total DM, \%BW & 1.88 & 2.10 & 1.98 & 2.09 & 2.06 \\
\hline NDF disappearance, $\% /$ hour $^{\mathrm{b}, \mathrm{d}}$ & 4.34 & 3.43 & 3.65 & 4.09 & 4.01 \\
\hline 96-hour NDF disappearance, $\%$ b & 75.0 & 73.8 & 74.0 & 73.1 & 73.4 \\
\hline Average ruminal $\mathrm{pH}^{\mathrm{b}, \mathrm{d}}$ & 6.30 & 6.22 & 6.22 & 6.12 & 6.19 \\
\hline Meals per dayc,e & 5.9 & 6.6 & 4.0 & 6.0 & 5.1 \\
\hline Time spent eating, $\mathrm{h}^{\mathrm{c}, \mathrm{e}}$ & 13.2 & 15.4 & 11.0 & 13.9 & 12.7 \\
\hline Meal size, $\mathrm{lb}^{\mathrm{c}, \mathrm{e}}$ & 4.1 & 2.6 & 4.8 & 3.2 & 3.9 \\
\hline
\end{tabular}

${ }^{\mathrm{a} C O N}=$ no supplement; DRC-D $=$ dry rolled corn supplement fed at $0.46 \%$ of BW daily; DRC-A $=$ DRC at $0.92 \%$ of BW on alternate days; DDG-D = dry distillers grains + solubles supplement fed at $0.45 \%$ of BW daily; DDG-A $=$ DDG at $0.90 \%$ of BW on alternate days.

${ }^{\text {b } C O N ~ v s ~ s u p p l e m e n t e d ~ t r e a t m e n t s, ~} P<0.05$

'Supplementation frequency effect, $P<0.10$

${ }^{\mathrm{d} D D G}$ vs DRC, $P<0.05$

'Supplement $\mathrm{x}$ frequency interaction, $P<0.08$

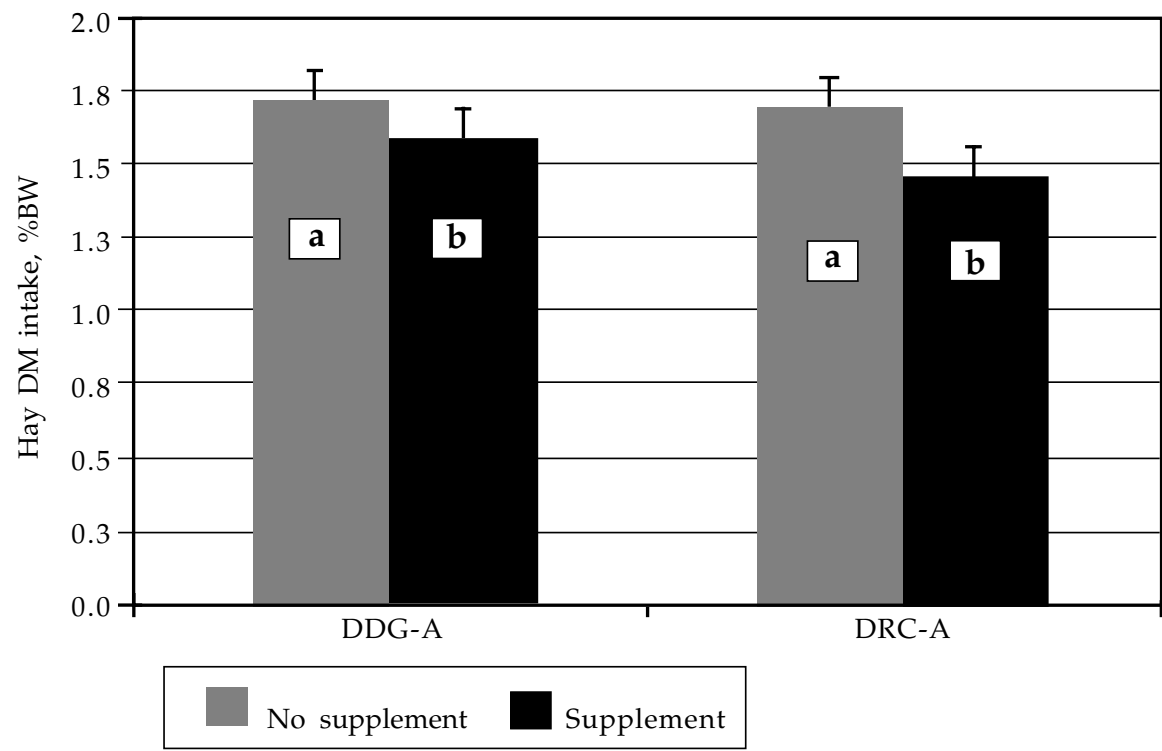

Figure 1. Effects of supplementation on voluntary hay intake among treatments supplemented every-other day. 'No supplement' = days supplement not fed. 'Supplement' = days supplement was fed. Bars with different letters are different $(P<0.01)$

Heifers received no supplement $(\mathrm{CON})$, dry distillers grains daily (DDG-D), dry distillers grains on alternating days (DDG-A), dry rolled corn daily (DRC-D), or dry rolled corn on alternating days (DRC-A; Table 1). Chopped grass hay $(8.2 \% \mathrm{CP})$ was fed for ad libitum consumption. Supplements were fed daily at $0.45 \%$ and $0.46 \%$ of BW for DRC-D and DDG-D, respectively. The small difference was to account for different inclusions of DRC or DDG in the supple-
8 , and 10 hour post-feeding; and $\mathrm{pH}$ was measured. Rate and extent of in situ disappearance were calculated with $0,12,24,48$, and 96hour incubations. Two incubations per period were conducted on heifers in alternate-day treatments. The 48-hour time point began on a supplement day for the first incubation, and a non-supplement day for the second.

Data were analyzed using the mixed procedure of SAS. Contrasts comparing CON vs supplemented treatments, daily vs alternate-day supplementation, and DRC vs DDG were included. Additionally, comparisons were made between days on which supplement was fed and non-supplementation days within the alternate-day treatments.

\section{Results}

Control heifers had higher $(P<0.01)$ hay DMI than supplemented heifers $(1.88 \%$ vs $1.66 \%$ BW, respectively); although totalDMI was lower $(P<0.01)$ for $\mathrm{CON}$ than supplemented $(1.88 \%$ vs $2.06 \% \mathrm{BW}$, respectively). An average of $3.7 \mathrm{lb}$ of supplement DM was fed per feeding in this trial. This level resulted in a substitution effect, regardless of the supplement type or frequency with which it was fed. Intake did not differ $(P=0.45)$ between DRC and DDG treatments.

Hay DMI was lower $(P=0.04)$ for heifers supplemented on alternating days $(1.62 \% \mathrm{BW})$ than for those supplemented daily (1.69\%BW). Previous research demonstrated a similar response with heifers supplemented three times weekly having lower intakes than those supplemented daily (2003 Nebraska Beef Report, pp. 8-10).

Within the alternate-day treatments, hay intake was $10.7 \%$ lower $(P<0.01)$ on days supplement was fed than on non-supplement days (Figure 1). Corn-supplemented heifers ate $13.8 \%$ less hay on supplementation days, compared to a $7.7 \%$ reduction for DDG-A. Hay

(Continued on next page) 
intake variation coupled with the supplementation schedule lead to large variation in daily dry matter intake among heifers in alternateday treatments. In general, reducing supplementation frequency had more marked effects on DRC treatments than on DDG (supplement $x$ frequency interaction, $P<0.08$; Table 2). Reducing DRC supplementation to every-other day reduced the number of meals by $39 \%$, time spent eating forage by $29 \%$, and increased meal size by $85 \%$. Reducing DDG supplementation frequency decreased meal number by $15 \%$, time spent eating forage by $9 \%$, and increased meal size by $22 \%$. Overall, heifers in alternate-day treatments ate fewer and larger meals, and spent less time eating than those supplemented daily (Table 2).
Control heifers had higher ( $P=0.04$ ) rate and extent of hay neutral detergent fiber (NDF) disappearance than supplemented heifers. Rate of hay NDF disappearance was lower $(P=0.02)$ for DRC than for DDG, although extent of disappearance was not significantly different between supplemented treatments. This may suggest that a negative associative effect was elicited by supplementation, and that the effect was exacerbated by supplementing corn.

Average rumen $\mathrm{pH}$ was greater $(P<0.01)$ for CON than supplemented heifers (6.30 vs 6.19, respectively). Heifers in the DDG treatments had lower $(P=0.03)$ ruminal $\mathrm{pH}$ than DRC heifers (6.15 vs 6.22 , respectively). Although lower rumen $\mathrm{pH}$ is generally associated with reduced forage digest- ibility, values above 6.0 are considered optimum for forage digestion. These $\mathrm{pH}$ differences may reflect increased VFA production resulting from increased rate of NDF disappearance observed in heifers within DDG treatments.

In conclusion, supplementation decreased hay intake and changed digestion kinetics. Reducing supplementation frequency affected amount and pattern of intake, and increased intake variation. Rate of hay NDF disappearance was greater in non-supplemented heifers compared to supplemented, and for DDG than DRC.

${ }^{1}$ Tim Loy, research technician; Jim MacDonald, research technician, Terry Klopfenstein, professor, Animal Science, Lincoln; Galen Erickson, assistant professor, Animal Science, Lincoln. 